Research Report No. 40/2013

\title{
Approximating Law and Development, Human Rights and Transitional Justice
}

Peer Zumbansen

Osgoode Hall Law School of York University, pzumbansen@osgoode.yorku.ca

Ruth Buchanan

Osgoode Hall Law School of York University, rbuchanan@osgoode.yorku.ca

Follow this and additional works at: http://digitalcommons.osgoode.yorku.ca/clpe

\section{Recommended Citation}

Zumbansen, Peer and Buchanan, Ruth, "Approximating Law and Development, Human Rights and Transitional Justice" (2013).

Comparative Research in Law \& Political Economy. Research Paper No. 40/2013.

http://digitalcommons.osgoode.yorku.ca/clpe/283 


\section{OSGOODE}

OSGOODE HALL LAW SCHOOL

YOR K U N I VERS I T Y

\section{OSGOODE HALL LAW SCHOOL}

Comparative Research in Law \& Political Economy

RESEARCH PAPER SERIES

Research Paper No. 40/2013

\section{Approximating Law and Development, Human Rights and Transitional Justice}

Peer Zumbansen \& Ruth Buchanan

Editors:

Peer Zumbansen (Osgoode Hall Law School, Toronto, Director Comparative Research in Law and Political Economy)

John W. Cioffi (University of California at Riverside)

Jonathan Ungaro (Osgoode Hall Law School, Toronto, Production Editor)

Comparative Research in Law \& Political Economy 


\title{
Approximating Law and Development, Human Rights and Transitional Justice
}

\author{
By Peer Zumbansen \& Ruth Buchanan
}

\begin{abstract}
:
This chapter is the introduction to the forthcoming edited collection "Law in Transition: Human Rights, Developments and Transitional Justice", edited by the authors and forthcoming with Hart Publishing (Oxford, 2013). The book will appear in the "Osgoode Reader" series and brings together many of the leading experts of the increasingly pertinent intersection of development, rights and transitional justice studies. The Introduction traces the theoretical and practical challenges of this discursive interaction and argues that it is only through such dialogue that a better understanding of the institutional and normative issues arising in contemporary law \& development and TJ contexts will be possible. The chapter provides an overview of the history of the law \& development movement, which is then discussed together with the rise of human rights theory and critique, especially against the background of decolonization, the rise of so-called 'Third World Approaches in International Law' [TWAIL], the rise and ambivalent aftermath of the Washington Consensus as well as the proliferation of post-conflict and law reform initiatives around the world. Transitional Justice, as a relatively young 'legal' field, brings to the table a host of interdisciplinary challenges arising from the complexity of post-conflict, state building and law reform contexts. The present chapter as well as the ensuing contributions to the edited collection highlight the importance of bringing these important fields in closer dialogue with each other.
\end{abstract}

Keywords: Law \& Development, Transitional Justice, Human Rights, Decolonization, Third World Approaches to International Law [TWAIL], Legal Anthropology, Global Governance, Law Reform, Contract, Property, Rule of Law,

\section{Information about the authors:}

Peer Zumbansen is Professor of Law at Osgoode Hall Law School, Toronto.

Email: PZumbansen@osgoode.yorku.ca

Ruth Buchanan is Associate Professor of Law at Osgoode Hall Law School, Toronto.

Email: RBuchanan@osgoode.yorku.ca 


\section{Approximating Law and Development, Human Rights and Transitional Justice}

Peer Zumbansen \& Ruth Buchanan, Osgoode Hall Law School

\section{INTERSECTIONS}

The contributions to this volume span the fast growing areas of "law and development", "transitional justice" and "human rights". The participating authors are well aware of the challenges which arise out of the attempt both to cross and to relativise boundaries, as well as to bridge discourses. And, perhaps, the apparent ease with which the authors convened here navigate the complexity of intersecting, in themselves continuously evolving, scholarly discourses and academic-political practices, might gloss over the intricacies of the exercise. But just how challenging the undertaking carried out by these authors really is becomes clearer when we realise that no area here is, in itself, easily categorised or mapped out with the aspiration of full comprehensiveness. Instead, the present volume intervenes at the crosssection of these three fields at a time in which considerable maturing, reflection and revisiting has been occurring for quite some time in each of the respective areas, prompting us both to take stock now and to highlight the nature of the overlap, dialogue and crossfertilisation of these discourses. The choice of our three areas of interest is by no means arbitrary: while "human rights" (HR) is arguably the "oldest" among the three legal fields in question here, it shares the inner complexity and dynamic content that characterise the other two. Law and development (L\&D) is itself a - comparatively - younger field, but one with a tremendously rich, layered and contested history. ${ }^{1}$ As scholars in the field have shown and as some of the contributors to this volume further illustrate, L\&D brings into dialogue a wide range of legal and non-legal fields, and thus becomes part of scholarly and policy discourses

For a seminal statement, see David Trubek \& Marc Galanter, "Scholars in Self-Estrangement: Some Reflections on the Crisis in Law and Development Studies in the United States", (1974) Wisconsin Law Review, p 1062); see, some thirty years later, the reflections in David Trubek \& Alvaro Santos, "Introduction: The Third Moment in Law and Development Theory and the Emergence of a New Critical Practice", in: David Trubek \& Alvaro Santos (eds), The New Law and Economic Development: A Critical Appraisal 1 (New York, Cambridge University Press, 2006). See, also, R. Buchanan, "A Crisis and its Afterlife: Some Reflections on 'Scholars in Self-Estrangement", in: G de Búrca, C Fitzpatrick \& J Scott (eds), Critical Studies of Global Governance: Liber Amicorum for David Trubek, (Oxford, Hart Publishing, 2013). 
ranging from "development studies", ${ }^{2}$ economics and economic geography, ${ }^{3}$ trade law ${ }^{4}$ to post-colonial studies. ${ }^{5}$ A similar intersection of theoretical and deeply practice-driven approaches can be observed in the third area which this book is placing under scrutiny: transitional justice. While more will be said on this field later in this introduction, it deserves mentioning that, like HR and L\&D, transitional justice (TJ) continues to defy a straightforward categorisation, be that with regard to its basic assumptions or its aspirations, ${ }^{6}$ its methodological foundations, as well as its theoretical versus practical aspirations. ${ }^{7}$

The following introduction seeks to set the stage for this cross-examination among the three fields of scientific inquiry involved, which we understand to include legal as well as socio-economic, cultural and political practice. The latter cluster of connections is of particular importance in view of the acute awareness among TJ scholars of the need both to expand and to deepen their agenda's reach in order to address, with a view to long-term sustainability, the trajectories and the persistence of the social and economic "grievances", 8 "inequalities", "structural violence" ${ }^{10}$ or "root causes" $" 11$ of societal conflict, exclusion and silencing. It will do so by first alluding to questions of context with regard to the emergence

2 JE Goldthorpe. The Sociology of Post-Colonial Societies: Economic Disparity, Cultural Diversity, and Development, (Cambridge, Cambridge University Press, 1996); Jeffrey Haynes, Development Studies, (Cambridge-Malden MA, Polity Press, 2008).

3 Paul A David, "Krugman's Economic Geography of Development: NEGs, POGs, and Naked Models in Space", (1999) 22 International Regional Science Review, p 162; Richard Peet, Unholy Trinity: The IMF, World Bank and WTO, 2nd ed. (London-New York, Zed Books, 2009).

4 Jagdish Bhagwati, The Economics of Underdeveloped Countries, (New York-Toronto: McGraw Hill, 1966); Jeffrey G. Williamson, Trade and Poverty: When the Third World Fell Behind, (Cambridge MA: MIT Press, 2011)

5 Arturo Escobar, Encountering Development: The Making and Unmaking of the Third World; with a new preface by the author, (Princeton NJ-Oxford: Princeton University Press, 2012); Sundhya Pahuja. Decolonising International Law: Development, Economic Growth and the Politics of Universality, (Cambridge: Cambridge University Press, 2011); Luis Eslava \& Sundhya Pahuja, "Between Resistance and Reform: TWAIL and the Universality of International Law", (2012) 3 Trade, Law and Development, p 103.

6 See, for example, the excellent analysis provided by Rama Mani, "Dilemmas of Expanding Transitional Justice, or Forging the Nexus between Transitional Justice and Development", (2008) 2 International Journal of Transitional Justice, p 253.

7 Christine Bell, "Transitional Justice, Interdisciplinarity and the State of the 'Field' or 'Non-Field"”, (2009) 3 International Journal of Transitional Justice, p 5.

8 Ismael Muvingi, "Sitting on Powder Kegs: Socioeconomic Rights in Transitional Justice", (2009) 3 International Journal of Transitional Justice, p 163.

9 Zinaida Miller, "Effects of Invisibility: In Search of the 'Economic' in Transitional Justice", (2008) 2 International Journal of Transitional Justice, p 266.

10 Ibid; see, also, Rosemary Nagy, Transitional Justice as Global Project: Critical Reflections, Chapter 13 in this volume.

11 Susan Marks, "Root Causes and Human Rights", (2011) 74 Modern Law Review, p 57. 
and continuing development of the three fields in a wider discursive universe of both "law and society" as well as, more recently, "law and globalisation" debates. ${ }^{12}$ By not only situating the three identified areas against this background but also highlighting the interaction among them, we hope to show how any assessment of these fields is bound to be but a momentary snap-shot, which only fleetingly highlights certain features, while, perhaps unduly, obscuring others. In bringing together some of the most renowned experts in the three areas, we hope to shed at least some light on the intricacies as well as the "stakes" methodological, and ultimately - political - in the areas under discussion here. Based upon the understanding that a primary objective of legal analysis ought to be the identification of the tension of "winning" versus the "losing" interpretations and applications of legal instruments, our aim here is first to relativise the alleged uniqueness of the three fields with regard to long existing, core legal areas - such as contract or tort, administrative or constitutional law. By highlighting how the interaction of such fields has, again and again, given rise to the formation of "new" legal areas, we can point to the dynamic of mutual responsiveness between legal norms and societal developments. While re-stating this very basic premise of legal sociology might seem trite and unnecessary to some contemporary readers, we argue that this dynamic demands renewed attention in a legal education and professional context that is shaped by at least two powerful trajectories. In the next section, we review the development of the three identified fields against the background of a significant shift which has been occurring both within law schools and within the world of legal practice.

12 For an elaboration of this idea, see Peer Zumbansen, "The Ins and Outs of Transnational Private Regulatory Governance: Legitimacy, Accountability, Effectiveness and a New Concept of "Context", (2012) 13 German Law Journal, p 1269; and idem., Sociological Jurisprudence 2.0: Updating Law's Interdisciplinarity in a Global Context, Chapter 18 in this volume. 


\section{BREAKING DOWN BOUNDARIES: "LAW AND SOCIETY", "LAW AND GLOBALISATION", LEGAL EDUCATION AND THE LEGAL PROFESSION}

In the light of the seemingly unfaltering creativity on the part of legal scholars to extend the boundaries of existing legal fields in response to pressures, say, from technological change, ${ }^{13}$ social transformation ${ }^{14}$ and from the fast proliferating spheres of social and institutional practice $^{15}$, the emergence and rapid consolidation of a "new" legal field has come to be seen as an ordinary event. ${ }^{16}$ And yet, it appears as though the memory of truly innovative fieldcreations in law - such as in the exemplary cases of environmental ${ }^{17}$ or cyberspace law ${ }^{18}$ - are quite short-lived, at least to the degree that scholars when they are confronted with the necessity (and, the opportunity) to reflect upon the ways in which law "reacts" to change, for example, under the rubrics of "internationalisation", or "globalisation", continue to lament the absence of reliable analytical frameworks and definitions. ${ }^{19}$ Meanwhile, the examples to be found in a field such as environmental law, which emerged from, and eventually grew beyond, tort law responsibility, ${ }^{20}$ or internet law, which both effectively, and irreversibly, ${ }^{21}$

13 Roger Brownsword \& Morag Goodwin, Law and the Technologies of the Twenty-first Century: Text and Materials, (Cambridge, Cambridge University Press, 2012); Alexia Herwig, "Transnational Governance Regimes for Foods Derived from Bio-Technology and their Legitimacy”, in: Christian Joerges, IngerJohanne Sand \& Gunther Teubner (eds), Transnational Governance and Constitutionalism, (Oxford, Hart Publishing, 2004), p 199.

14 Lucinda Peach, Legislating Morality: Pluralism and Religious Identity in Lawmaking, (New York, Oxford University Press, 2002); Karl-Heinz Ladeur \& Ino Augsberg, "The Myth of the Neutral State: The Relationship between State and Religion in the face of New Challenges", (2007) 8 German Law Journal, p 143; Abdullahi Ahmed An-Na'im, Islam and the Secular State: Negotiating the Future of Shari'a, (Cambridge MA, Harvard University Press, 2008).

15 David G Post, “Anarchy, State, and the Internet: An Essay on Law-Making in Cyberspace”, (1995) Journal of Online Law, available at: http://www.temple.edu/Lawschool/dpost/Anarchy.html; Julia Hörnle, "Disputes Solved in Cyberspace and the Rule of Law", (2001) 7 The Journal of Information, Law and Technology, (now renamed the European Journal of Law and Technology), available at: http://www2.warwick.ac.uk/fac/soc/law/elj/jilt/2001_2/hornle; Viktor Mayer-Schönberger \& Malte Ziewitz, Jefferson Rebuffed: The United States and the Future of Internet Governance, (2007) 8 Columbia Science and Technology Law Review, p 188.

16 For the field of international law, see the remarkable essays in: Fleur Johns, Richard Joyce \& Sundhya Pahuja (eds), Events: The Force of International Law, (London, Routledge-Cavendish, 2011).

17 Gunther Teubner, Lindsay Farmer \& Declan Murphy (eds), Environmental Law and Ecological Responsibility: The Concept and Practice of Ecological Self-Organization, (Hoboken NJ, John Wiley and Sons, 1994).

18 Lawrence Lessig, "The Law of the Horse: What Cyberlaw might Teach", (1999) 113 Harvard Law Review, p 501.

19 Ralf Michaels, "Globalization and Law: Law Beyond the State”, in: Reza Banakar \& Max Travers, Law and Social Theory, 2nd ed., (Oxford-Portland OR, Hart Publishing, forthcoming); available at: http://scholarship.law.duke.edu/faculty_scholarship/2862, ms. at 1.

20 Grant Gilmore, The Death of Contract, (Columbus OH, Ohio State University Press, 1974); Duncan 
pushed beyond the confines of constitutional law and private law, ${ }^{22}$ can be seen as important reminders of law's evolutionary nature, ${ }^{23}$ causing it to resist ascriptions of simple causality or mere linear trajectory. ${ }^{24}$ With these examples in mind, and although we can easily recognise the aspirations among our contemporaries to attribute an adequate label or even a specific status to emerging legal frameworks, we should nevertheless be mindful of the de facto normality of such struggles. In effect, such labelling anxieties multiply in the face of greater complexity, which serve to challenge the law in both form and substance with the alleged "new-ness" of a situation. In other words, law's relation to society in its ever-changing nature has always been a dynamic shaped by the competing forces of change and resistance, misunderstanding, over-reach, trial and error. ${ }^{25}$

Compared to the immensely rich, and, at the same time, precarious research and policy agenda of "law and society", 26 the formula "law and globalisation" describes a more

Kennedy, "Distributive and Paternalist Motives in Contract and Tort Law, with Special Reference to Compulsory Terms and Unequal Bargaining Power, (1982) 41 Maryland Law Review, p 563; Peter H Schuck, Tort Law and the Public Interest: Competition, Innovation, and Consumer Welfare, (New York, WH Norton, 1991). Lawrence Lessig, Code and other Laws of Cyberspace, (New York, Basic Books, 1999).

Henry H. Perritt Jr., "The Internet is changing the Public International Legal System", (2000) 88 Kentucky Law Review, p 885; Jochen von Bernstorff, "The Structural Limitations of Network Governance: ICANN as a Case in Point", in: Christian Joerges, Inger-Johanne Sand \& Gunther Teubner (eds), Transnational Governance and Constitutionalism, (Oxford, Hart Publishing, 2004), p 257; Lucile M Ponte \& Thomas D Cavenagh, Cyberjustice: Online Dispute Resolution (ODR) for E-Commerce, (Upper Saddle River NJ: Prentice Hall, 2004).

Simon Deakin, "Evolution for our Time: A Theory of Legal Memetics", ESRC Centre for Business Research, University of Cambridge Working Paper No. 242 (also published in (2002) 55 Current Legal Problems, pp 1-42), available at: www.cbr.cam.ac.uk/pdf/WP242.pdf; Peer Zumbansen \& Gralf-Peter Calliess, "Law, Economics and Evolutionary Theory: State of the Art and Interdisciplinary Perspectives", in: Peer Zumbansen \& Gralf-Peter Calliess (eds), Law, Economics and Evolutionary Theory, (CheltenhamNorthampton MA, Edward Elgar Publishing, 2011), p 1.

For the case of constitutional law, see Niklas Luhmann, "Verfassung als evolutionäre Errungenschaft", (1989) 9 Rechtshistorisches Journal, p 176; see, also, Robert M Cover, "Nomos and Narrative", (1983) 97 Harvard Law Review, p 4, and Ernest A Young, "The Constitution outside the Constitution", (2007) 117 Yale Law Journal, p 408.

25 See, for example, Lawrence M Friedman, "Coming of Age: Law and Society Enters an Exclusive Club", (2005) 1 Annual Review of Law and Social Sciences, pp 1-16; Ruth Buchanan, Stewart Motha \& Sundhya Pahuja, "Introduction", in: Ruth Buchanan, Stewart Motha \& Sundhya Pahuja (eds), Reading Modern Law: Critical Methdologies and Sovereign Formations, (Abingdon-New York, Routledge, 2012), p 1; Peer Zumbansen, "Law's Effectiveness and Law's Knowledge: Reflections from Legal Sociology and Legal Theory", (2009) 10 German Law Journal, p 417.

26 Boaventura de Sousa Santos, "Law: A Map of Misreading. Toward a Postmodern Conception of Law", (1987) 14 Journal of Law \& Society, p 279; Gunther Teubner, "How the Law Thinks: Toward a Constructivist Epistemology of Law", (1989) 23 Law \& Society Review, p 727; Roger Cotterrell, "Why must Legal Ideas be Interpreted Sociologically?”, (1998) 25 Journal of Law \& Society, p 171; Bryant Garth \& Joyce Sterling, "From Legal Realism to Law \& Society: Reshaping Law for the Last Stages of the Social 
recent, but already no longer the newest, attempt at capturing the general meaning of law's operations in an increasingly interconnected global space. ${ }^{27}$ Questioning existing methodologies, legal scholars, sociologists and anthropologists are examining the analytical and conceptual toolkits, the institutional orientation and normative value judgements that are employed in the multi- and inter-disciplinary context of globalisation studies. ${ }^{28}$ Meanwhile, the challenge for lawyers and institutional educators to interpret and to translate the challenges of a globalising world into effective legal practice ${ }^{29}$ as well as into the realities of a law-school classroom has only become greater. ${ }^{30}$ It seems promising, then, that legal scholars have been showing a growing interest in better understanding the widely-varied phenomena of globalisation and its impact on law, legal research and legal education. ${ }^{31}$ And, yet, despite ever-increasing efforts by lawyers and social scientists to study the complex

Activist State", (1998) 32 Law \& Society Review, p 409; Elizabeth Heger Boyle \& John W. Meyer, "Modern Law as a Secularized and Global Model: Implications for the Sociology of Law", in: Yves Dezalay \& Bryant Garth (eds), Global Prescriptions. The Production, Exportation, and Importation of a New Legal Orthodoxy, (Ann Arbor, University of Michigan Press, 2002.

See the highly influential study by Manuel Castells, The Rise of the Network Society: Information Age: Economy, Society and Culture, vol. I., 2nd ed., 2000, (Oxford-Cambridge MA, Blackwell Publishing, 1996), and two exemplary and very helpful depictions of the ways in which law has been reacting to globalization phenomena: Gunther Teubner, "The King's Many Bodies: The Self-Deconstruction of Law's Hierarchy", (1997) 31 Law \& Society Review, p 763, and Paul Schiff Berman, "From International Law to Law and Globalization”, (2005) 43 Columbia Journal of Transnational Law, p 485.

See, for example, David M. Trubek, Yves Dezalay, Ruth Buchanan and John R. Davis, "Global restructuring and the law: Studies in the internationalization of legal fields and the creation of transnational arenas", (1994) 44 Case Western Reserve Law Review, p 407; Jean Comaroff \& John L Comaroff, Theory from the South: Or, How Euro-America is Evolving Toward Africa (The Radical Imagination), (New York, Paradigm Publishers, 2011); Dipesh Chakrabarty, Provincializing Europe: Postcolonial Thought and Historical Difference, 2nd ed., [orig. 2000] (Princeton NJ, Princeton University Press, 2007).

29

See, recently, the contributions to Yves Dezalay \& Bryant G. Garth (eds.), Lawyers and the Construction of Transnational Justice, (Oxford, Routledge, 2012); Harry W Arthurs \& Kreklewich, "Law, Legal Institutions, and the Legal Profession in the New Economy", (2000) 34 Osgoode Hall Law Journal, p 1; Mary C Daly, "The Ethical Implications of the Globalization of the Legal Profession: A Challenge to the Teaching of Professional Responsibility in the Twenty-First Century", (1998) 21 Fordham International Law Journal, p 1239.

30 Craig Scott, "A Core Curriculum for the Transnational Legal Education of JD and LLB Students: Surveying the Approach of the International, Comparative and Transnational Law Program at Osgoode Hall Law School", (2005) 23 Pennsylvania State International Law Review, p 757; Gerald Torres, "Integrating Transnational Legal Perspectives Into the First Year Curriculum", (2005) 23 Pennsylvania State International Law Review, p 801; Helge Dedek \& Armand de Mestral, “'Born to be Wild': The 'Transsystemic' Programme at McGill and the De-Nationalization of Legal Education", (2009) 10 German Law Journal, p 889; Peer Zumbansen, “Transnational Law, Evolving”, in: Jan M Smits (ed), Elgar Encyclopedia of Comparative Law, 2nd ed., (Cheltenham-Northampton MA, Edward Elgar Publishing, 2012), p 898.

31 See the Symposia: "Navigating the Transsystemic-Tracer le Transsystemique", (2005) 50 McGill Law Journal, pp 701-984, and Nadia Chiesa, Adam de Luca \& Bernadette Maheandiran (eds), "Following the Call of the Wild: The Promises and Perils of Transnationalizing Legal Education", (2009) 10 German Law Journal, special issue, pp 629-1168, available at: http://germanlawjournal.com/pdfs/FullIssues/Vol_10_No_07.pdf. 
relationship between domestic and global regulatory developments, ${ }^{32}$ when can we actually be sure that the conceptual toolkits used in these undertakings are adequate? The same doubts appear to haunt (at least some areas of) legal education. While it is true that law schools around the world have been addressing the perceived need to adapt their curricula to the evolving prospects of a legal profession with an increasingly global reach, ${ }^{33}$ most of such institutional undertakings remain marked by a concern which, first and foremost, regards the design of programmes that will provide graduates with the skills to offer optimal legal services in both domestic and global settings. ${ }^{34}$ As a result, law school curriculum reformers, in trying to strike a balance between these two universes of legal practice, are prone to add introductory courses (such as "Law and Globalization", "Ethical Lawyering in a Global Context") to their curriculum, while, often enough, bowing to the pressures of the bar to maintain a distinct focus on core, black letter, "bread and butter" courses. Meanwhile, and despite a long-standing, and continuing, tradition to push for a contextual study of business relations embedded in sociological analysis, ${ }^{35}$ seminars in comparative or transnational law, legal culture or legal anthropology, and even international business transactions or international business law, are usually only taken by a self-selected group of specialised students in their last year of law school.

This "fence-sitting" is reflected, at least in part, in large parts of legal research; legal scholars, if the scope of research disseminated on the Social Science Research Network (www.ssrn.com) is any indication, likewise appear to focus their interests on matters of domestic significance, thus reflecting the primary orientation of legal practice for the majority of law school graduates. The world "outside" the nation state, even that of another

32 Saskia Sassen, “The State and Globalization”, in: Joseph S Nye \& John D Donahue (eds), Governance in a Globalizing World, (Washington DC, Brookings Institute, 2000), p 91; Alec Stone Sweet, "Constitutionalism, Legal Pluralism, and International Regimes", (2009) 16 Indiana Journal of Global Legal Studies, p 621.

33 For one of the most recent examples, see the case of New York University School of Law's expansion through new law school campuses in Buenos Aires, Paris and Shanghai: available at: http://www.law.nyu.edu/news/NYU_LAW_ANNOUNCES_STUDYABROAD_PROGRAM_CURRICULAR_ENHANCEMENTS_THIRD_YEAR.

34 See James Vescovi, "Why Does Law School Cost So Much?”, Columbia Law School, Communication Report, Summer 2006, available at: https://www.law.columbia.edu/law_school/communications/reports/summer06/lawschoolcost.

35 Stewart Macaulay, "Elegant Models, Empirical Pictures, and the Complexities of Contract", (1977) 11 Law \& Society Review, p 507; Gregory C Shaffer, "How Business Shapes Law: A Socio-Legal Framework", (2009) 42 Connecticut Law Review, p 147. 
nation state, remains one in which the majority of legal scholars is either not that interested, or sceptical about. ${ }^{36}$ In contrast, then, while the apparently "transnational" scope of EU law appears to be a logical consequence of "Europeanisation" processes, there is also the risk of a distinct blind-side. Pushing the boundaries of the European legal imagination towards a greater appreciation of the significance of studying law from both a comparative and, specifically, from a European and "integrationist" perspective, this energy-consuming effort sometimes has the tendency to push aside and, effectively, to render invisible important advances in the study of different countries' (Member States') law's historical and colonial pasts. $^{37}$ This sometimes manifests itself in an apparent nonchalance towards the nation states' "darker legacies" ${ }^{38}$ as well as to their socio-economic specificities and their undeniable impact on European legal harmonisation projects. ${ }^{39}$ This orientation towards the (once) bright lights of the European integration process today produces a strangely intriguing mixture of mundane love-of-self-as-consumer, on the one hand, ${ }^{40}$ and a maturing interest in developing interdisciplinary research agendas to study the EU's deeper embeddedness in its colonial past, on the other.

In what could be seen as a parallel universe that persists in the blind spots of mainstream legal education today, increasingly sophisticated research approaches have been developing with regard to the prospects of and the forms in which legal analytical instruments

Martha Minow, "The Controversial Status of International and Comparative Law in the United States", (2010) 52 Harvard International Law Journal Online, available at: http://www.harvardilj.org/wp. But, see Christian Joerges, "Working through 'bitter experiences' towards a purified European identity: a critique on the disregard for history in European constitutional theory and practice", in: Erik Oddvar Eriksen, Christian Joerges \& Florian Rödl (eds), Law, Democracy and Solidarity in a Post-national Union: the Unsettled Political Order of Europe, (Oxford-New York, Routledge, 2006), p 335.

38 See Joseph HH Weiler, "Epilogue", in: Christian Joerges \& Navraj Singh Ghaleigh (eds), Darker Legacies of Law in Europe: The Shadow of National Socialism and Facism over Europe and its Legal Tradition, (Oxford, Hart Publishing, 2003), p 389; see the extensive commentaries on the project on the "Darker Legacies of Law in Europe" in the Symposium: "European Integration in the Shadow of Europe's Darker Past: The 'Darker Legacies of Law in Europe' Revisited", (Daniel Augenstein (ed)) (2006) 7 German Law Journal, pp 71-256.

39 Christian Joerges, Bo Stråth \& Peter Wagner (eds), The Economy as a Polity: The Political Constitution of Contemporary Capitalism, (London, UCL Press, 2005); specifically on the area of corporate governance, see also the insightful essay by one of Europe's great comparatists: Klaus J Hopt, "Common Principles of Corporate Governance in Europe?", in: Joseph A McCahery, Piet Moerland, Theo Raaijmakers \& Luc Renneboog (eds), Corporate Governance Regimes: Convergence and Diversity, (Oxford, Oxford University Press, 2002), p 175.

40 Alexander Somek, “Accidental Cosmopolitanism”, (2012) 3 Transnational Legal Theory, p 371.

41 Philipp Dann \& Felix Hanschmann, "Post-colonial Theories and Law", (2012) 45 Law and Politics in Africa, Asia, Latin America - Verfassung und Recht in Übersee (VRÜ), p 123. 
and concepts - categories as well as basic understandings of nation state-originating legal institutions and processes - might, or might not, be adaptable to the regulatory challenges in a

global space. ${ }^{42}$ In this vein, scholarship on "law and globalisation" appears to have become an industry in its own right. Yet, the focal point of this burgeoning scholarship remains far from precise. In other words, it does not seem evident what precisely or specifically is the question that law and globalisation scholars are actually trying to answer. What does seem clear, at the same time, is that the endeavours of legal scholars in this context have long become part of a multi-disciplinary study of global governance. As such, "law and globalisation" has become a field of scholarly inquiry that is belaboured by lawyers, political scientists, sociologists, anthropologists, geographers and political economists alike, which raises - yet again - important questions about how law should situate itself in relation to the approaches and methods of other disciplines.

\section{HUMAN RIGHTS, LAW \& DEVELOPMENT AND TRANSITIONAL JUSTICE AS LEGAL FIELDS ${ }^{43}$}

The contributions to the present volume can be read against the above-described background of an increasingly rich overlay of disciplinary engagements with globalisation phenomena. A distinctive trait of these engagements is the recognition that the success of any inquiry depends on the awareness of the methodological challenges arising from the unruly nature of the object or objects under scrutiny. Transitional justice, one of our core fields in this essay collection, is a case in point. ${ }^{44}$ The same applies, arguably, to law and development [L\&D], a field which has always been an area which can neither be neatly and clearly defined nor boxed into clear-cut categories. L\&D has long been a battle field for opposing concepts of law, political and economic order and the role of institutional governance, ${ }^{45}$ and, as such, has

42 A rich account and analysis is offered by William Twining. Globalisation and Legal Theory, (Evanston IL: Northwestern University Press, 2000); see, also, the Symposium on Twining's 2011 Montesquieu Lecture at Tilburg University on "Globalization and Legal Research", in: (2013) 4:3 Transnational Legal Theory.

43 The following section draws on Peer Zumbansen, "Knowledge in Development and Regulation, or How do we Distinguish between the Economic and the Non-Economic?”, in: Búrca, Fitzpatrick \& Scott (eds.), note 1 above.

44 Bell, note 7 above, p 5, at 7: “[...], by 2009, we have a broad, multidisciplinary field that subjects its own origins, assumptions and political significance to radical critique. Unlike other fields of study, which have taken decades to reach this point, transitional justice can be argued to have experienced a dramatically compressed trajectory of fieldhood."

45 D Kennedy, "Laws and Development", in: J Hatchard \& A Perry-Kessaris (eds), Law and Development: Facing Complexity in the 21st Century - Essays in Honour of Peter Slinn (London, Cavendish Publishing Limited, 2003), p 17. 
served as a laboratory for audacious experiments with explosive material. Categories such as "progress", "d6 "development" $\mathrm{Law}^{48}$ are invariably contentious concepts, and, in the context of $\mathrm{L} \& \mathrm{D}$, frequently employed as bargaining chips in a high-stakes game over political and economic influence, autonomy and, emancipation. ${ }^{49}$ While specific local contexts of L\&D became the loci of such contestation, often enough under the magnifying glass of international and national development agendas, market integration and state reform, ${ }^{50}$ one of the most striking discoveries to be made here relates to the fact that the contentious items in the L\&D context are also those which have long informed a critical analysis of law and governance in the context of the nation state. ${ }^{51}$ As such, the boundaries between the developing and the developed world, between those countries receiving and those exporting or providing legal (or economic) aid, become porous, and a legal theory of L\&D can fruitfully build on its older domestic sister.

Among the important scholarly projects pursued by L\&D scholars has been the discovery and analysis of the legal pluralist nature of the governance orders in the context of development. ${ }^{52}$ With a growing awareness of the different, existing ordering structures "on the ground" in the development context came the realisation that any legal order challenges the observer to acknowledge the parallels between, and the co-existence of, formal and informal, hard and soft law, of legal and non-legal norms. ${ }^{53}$ This realisation prompted L\&D

46 Thomas Skouteris, The Notion of Progress in International Law Discourse, (The Hague, T.M.C. Asser Press, 2010); Usha Natarajan, "TWAIL and the Environment: The State of Nature, the Nature of the State, and the Arab Spring”, (2012) 14 Oregon Review of International Law, p 177.

47 Escobar, note 5 above.

48 Jothie Rajah, Authoritarian Rule of Law: Legislation, Discourse and Legitimacy in Singapore, (New York, Cambridge University Press, 2012).

49 For a brilliant deconstruction of the post-war conceptual division between political and economic emancipation of former colonial states, see Pahuja, Decolonising International Law, note 5 above.

50 World Bank, World Development Report 1996: From Plan to Market, (Oxford-New York, Oxford University Press, 1996).

51 The masterful analysis is still Trubek \& Galanter, "Scholars in Self-Estrangement", note 1 above).

52 K Pistor \& D Berkowitz, "Of Legal Transplants, Legal Irritants, and Economic Development”, in: P Cornelius \& B Kogut (eds), Corporate Governance and Capital Flows in a Global Economy, (Oxford, Oxford University Press, 2003), p 347; K Pistor, "The Standardization of Law and its Effect on Developing Economies”, (2002) 50 American Journal of Comparative Law, p 97.

53 HW Arthurs, Without the Law: Administrative Justice and Legal Pluralism in Nineteenth Century England (Toronto, University of Toronto Press, 1988); RA Macdonald \& J MacLean, "No Toilets in Park", (2005) 50 McGill Law Journal, p 721; SF Moore, "Law and Social Change: The Semi-Autonomous Field as an 
scholars not only to acknowledge but also to build upon the idea that many of the challenges pertaining to a law/non-law distinction that had been identified as specific to the development context, were, in fact, detachable from any legal governance framework. Indeed, the inadequacy of the existing legal governance thinking pointed to the need for a different theoretical - but also, doctrinal - attention. ${ }^{54}$

It is this realisation that allows for a better appreciation of the questionable foundations of a legal "order", of the embeddedness of legal governance in a particular institutional setting (for example, the "state") and at a particular moment in (geo-political) time. ${ }^{55}$ To the degree that the struggle over law "reform" in the context of development is seen as not entirely removed from contestations of the legal (political, economic) order in the domestic context, ${ }^{56}$ L\&D emerges as a field, which is just as much concerned with the relationship of law to its (particular, local) social environment and context as that has been the case for all other legal theoretical or legal sociological inquiries. ${ }^{57}$ But, accepting this perspective also implies accepting the loss of an outside observer's standpoint. Precisely by acknowledging the inseparability of critical legal analysis in the domestic and the "development" context, we lose the comfort of being "outside" the very sphere which we are purporting both to study and to examine in a disinterested manner. ${ }^{58}$ Instead, the demarcation of the L\&D context from that of one's home legal system and jurisdiction becomes questionable in itself, because the assertions of law's precariousness in the development context apply to the domestic home context with equal force. Upon this basis, the distinction between governance challenges of "there" and "here" appears artificial. Indeed, the distinction seems designed to insulate the domestic context from critique while depicting the development context as deficient and requiring "aid" and assistance. The identification of a

Appropriate Subject of Study”, (1973) 7 Law \& Society Review, p 719.

Macdonald \& MacLean, see note above. See, also, Scott, note 30 above, p 757.

55

56

Begoña Aretxaga, "Maddening States", (2003) 32 Annual Review of Anthropology, p 393.

David Kennedy, "Challenging Expert Rule: The Politics of Global Governance”, (2005) 27 Sydney Journal of International Law, p 5.

57 Cotterrell, note 26 above, p 171; R Banakar, "Law Through Sociology's Looking Glass: Conflict and Competition in Sociological Studies of Law”, in: A Denis \& D Kalekin-Fishman (eds), The ISA Handbook in Contemporary Sociology, (London, Sage Publications, 2009); P Zumbansen, "Law's Effectiveness and Law's Knowledge: Reflections from Legal Sociology and Legal Theory”, (2009) 10 German Law Journal, p 417.

58 Trubek and Galanter, note 1 above. See, also, DM Trubek, "Toward a Social Theory of Law: An Essay on the Study of Law and Development”, (1972) 82 Yale Law Journal, p 1. 
series of legal governance questions as arising from within the context of a "developing country" inevitably leads to these questions having to be seen as being already pertinent much "earlier", namely, already present and evident in the context of domestic legal critique.

A striking feature of this contextualisation of L\&D as part of a larger exercise in investigating law's relationship to and its role in society, is the way in which the field opens itself up to an engagement and exchange with complementary discourses about regulatory places and spaces. Both legal scholars ${ }^{59}$ and sociologists ${ }^{60}$ have been scrutinising the conceptual and constituted nature of such regulatory spaces; spaces which escape a straightforward depiction from a single discipline's vantage point. Just as this critique has become pertinent with regard to the analysis of different, specialised regulatory arenas, ranging from labour ${ }^{61}$ to corporate law, ${ }^{62}$ from environmental ${ }^{63}$ to criminal law, ${ }^{64}$ altogether suggesting a methodological shift from comparative to transnational law, ${ }^{65}$ L\&D has become

59 R Ford, "Law's Territory (A History of Jurisdiction)”, (1999) 97 Michigan Law Review, p 843; R. Buchanan, "Border Crossings: NAFTA, Regulatory Restructuring and the Politics of Place", (1995) Indiana Journal of Global Legal Studies, pp 371-393.

Sassen, "The State and Globalization", note 32 above, p 91; idem, "The Places and Spaces of the Global: An Expanded Analytic Terrain", in: David Held \& Anthony G McGrew (eds), Globalization Theory: Approaches and Controversies, (Cambridge-Malden MA, Polity Press, 2007), p 79; D Harvey, "The Sociological and Geographical Imaginations", (2005) International Journal of Politics, Culture and Society, p 211.

61 DM Trubek, J Mosher \& JS Rothstein, "Transnationalism and the Regulation of Labor Relations: International Regimes and Transnational Advocacy Networks", (Labor and the Global Economy Research Circle, The International Institute, University of Wisconsin-Madison, January 1999 (n 7); G Mundlak, "DeTerritorializing Labor Law", (2009) 3 Law \& Ethics of Human Rights, p 188; HW Arthurs, "Extraterritoriality by other Means: How Labor Law sneaks across Borders, Conquers Minds, and Controls Workplaces Abroad”, (2010) 21 Stanford Law \& Policy Review, p 527.

62 LC Backer, "Private Actors and Public Governance Beyond the State: The Multinational Corporation, the Financial Stability Board, and the Global Governance Order", (2011) 18 Indiana Journal of Global Legal Studies, p 751; P Zumbansen, 'Neither 'Public' nor 'Private', 'National' nor 'International': Transnational Corporate Governance from a Legal Pluralist Perspective”, (2011) 38 Journal of Law \& Society, p 50.

63 L Gulbrandsen, S Andresen \& JB Skjærseth, "Non-State Actors and Environmental Governance: Comparing Multinational, Supranational and Transnational Rule Making”, in: B Reinalda (ed), The Ashgate Research Companion to Non-State Actors, (Farnham-Burlington VT, Ashgate Publishing, 2011), p 463; N Craik, "Deliberation and Legitimacy in Transnational Environmental Governance", (2006) IILJ Working Paper 2006/10, New York University, Global Administrative Law Series; C Kamphuis, "Canadian Mining Companies and Domestic Law Reform: A Critical-Legal Account", (2012) 13 German Law Journal 1456; S Seck, "Home State Regulation of Environmental Human Rights Harms as Transnational Private Regulatory Governance", (2012) 13 German Law Journal, p 1360.

64 N Boister, "Transnational Criminal Law?", (2003) 14 European Journal of International Law, p 953; N Boister, An Introduction to Transnational Criminal Law, (Oxford, Oxford University Press, 2012); RJ Currie, International and Transnational Criminal Law, (Toronto, Irwin Law, 2010).

65 CM Scott, “"Transnational Law' as Proto-Concept: Three Conceptions”, (2009) 10 German Law Journal, p 859; P Zumbansen, "Transnational Legal Pluralism", (2010) 1 Transnational Legal Theory, p 141; Zumbansen, "Transnational Law, Evolving", note 30 above. 
a very active sphere for a renewed, critical and contextual analysis of law in a fast-changing and volatile environment.

This aspect has been underlined, perhaps most tellingly, by the recent approximation of L\&D with the field of "transitional justice", which testifies to an increasing awareness among interested experts of the close connections between investigations into the "legacies" of past injustices with programmes of future-directed legal and economic aid. ${ }^{66}$ It is this disciplinary overlap and the growing intersections between L\&D and TJ which allows for a critical investigation into their "shared logics", 67 as several of the authors to the present collection illustrate. Due to concerns of space, the editors decided to omit the inclusion of one, closely-related field of scholarly analysis - literary critique, which prominently draws on novels and poetry to shed light on the relations between literature and academic trajectories of development, transitional justice and post-colonial studies. ${ }^{68}$ Among such literature, we find works that treat themes closely connected to, and often overlapping with, the noted scholarly engagement: here, we find a vibrant "literary" "transition" periods. After the seminal (inevitably colonial) portrayals by Joseph Conrad in "An Outpost of Progress" (1897) or "Heart of Darkness" (1899), post-colonial novels such as the late Chinua Achebe's "Things Fall Apart" (1958) and JM Coetzee's "Waiting for the Barbarians" (1980) poignantly scrutinise the slippery slope between "us" and "them" that inescapably pervades any "intervention" or "development" context. As Anne Orford has described in the context of public international law's attempts to address transnational military and civil conflict, we need to take a close look at the hidden, hegemonic aspirations of recent instances of "humanitarian intervention". 70 Excavating the challenges of concepts such as "change", "reform" and "progress", as they have been central to seminal transitional

66 See, for example, R Mani, "Dilemmas of Expanding Transitional Justice, or Forging the Nexus between Transitional Justice and Development", (2008) 2 International Journal of Transitional Justice, p 253, and the contributions to $\mathrm{P}$ de Greiff \& R Duthie (eds), Transitional Justice and Development: Making Connections, (New York, Social Science Research Council, 2009).

67 Christopher J Colvin, "Purity and Planning: Shared Logics of Transitional Justice and Development”, (2008) 2 International Journal of Transitional Justice, p 412.

68 See Edward W Said, Orientalism, (New York, Vintage Books, 1978), and Achille Mbembe, On the Postcolony, (Berkeley LA-London, University of California Press, 2001);

69 See the insightful discussion of the prose/poetry debate in India around the work of Rabindranath Tagore, in D Chakrabarty, Provincializing Europe: Postcolonial Thought and Historical Difference, 2nd ed., first published 2000, (Princeton NJ, Princeton University Press, 2007).

70 A Orford, "Muscular Humanitarianism: Reading the Narratives of the New Interventionism", (2003) 10 European Journal of International Law, p 679. 
justice debates as those concerning South Africa ${ }^{71}$ or Sri Lanka, ${ }^{72}$ Achmat Dangor's "Bitter Fruit" (2001) ${ }^{73}$ or films such as Prasanna Vithanage's Death on a Full Moon Day, have become inseparably intertwined with the scholarly, "expert" discourse around these instances of transitional justice. ${ }^{74}$

The essays in the present collection are authored by scholars with a wide range of scholarly expertise as well as practical experience in L\&D and TJ. These two areas have become pivotal signifiers of the ways in which lawyers interested in comparative and international law have - over time - developed very focused and nuanced approaches to the dynamics that characterise the emerging political and legal orders. Such transition states often result, for example, from military and/or political transformation due to either violent regime change or peaceful democratic transition, and raise pressing questions regarding the role of, say, criminal law and the persecution of the previous regime's human-rights violations or that of international law in assisting or facilitating the new regime's legal-political consolidation. ${ }^{75}$ With an almost overwhelming number of aspects to be addressed in a volatile development or transition context, scholars have fruitfully been debating how law, possibly aided by other disciplines, can adequately identify, address, and eventually remedy the virulent questions arising in such contexts. In this vein, one of the field's leading scholars, has observed that:

"The universe of transitional justice can be broadly or narrowly defined. At its broadest, it involves anything that a society devises to deal with a legacy of conflict and/or widespread human rights violations, from changes in criminal codes to those in high school textbooks, from creation of memorials, museums and days of mourning, to police and court reform, to tackling the distributional inequities that

71 H Corder, "Prisoner, Partisan and Patriarch: Transforming the Law in South Africa 1985-2000", (2002) 118 The South African Law Journal, p 772; A Gross, "Reconciliation in South Africa", (2004) 40 Stanford Journal of International Law, p 40.

72 J Derges, Ritual and Recovery in Post-Conflict Sri Lanka, (London, Routledge, 2012).

73 Hugh Corder, "Prisoner, Partisan and Patriarch: Transforming the Law in South Africa 1985-2000", (2002) 118 The South African Law Journal, p 772; Aeyal Gross, "Reconciliation in South Africa", (2004) 40 Stanford Journal of International Law, p 40.

74 See, for example, Gordon Weiss, The Cage: The Fight for Sri Lanka and The Last Days of the Tamil Tigers, (London, Bodley Head, 2011).

75 Richard J Goldstone, "Foreword", in: Martha Minow, Between Vengeance and Forgiveness: Facing History after Genocide and Mass Violence, (Boston MA, Beacon Press, 1999), pp ix-xiii; Nehal Bhuta, "New Modes and Orders: The Difficulties of a Jus Post Bellum of Constitutional Transformation", (2010) 60 University of Toronto Law Journal, p 799. 
underlie conflict. A narrow view can be criticized for ignoring root causes and privileging civil and political rights over economic, social or cultural rights, and by so doing marginalizing the needs of women and the poor. On the other hand, broadening the scope of what we mean by transitional justice to encompass the building of a just as well as peaceful society may make the effort so broad as to become meaningless. ${ }^{76}$

Ruti Teitel, author of the widely acclaimed 2000 monograph on Transitional Justice, put the following questions at the outset of her investigation:

"How should societies deal with their evil pasts? [...] How is the social understanding behind a new regime committed to the rule of law created? Which legal acts have transformative significance? What, if any, is the relation between a state's response to its repressive past and its prospects for creating a liberal order? What is law's potential for ushering in liberalization?"

These questions have since been taken up within a wide range of scholarly and practical engagement, leading, inter alia, to the creation or further consolidation of specialised research institutions, including the International Center for Transitional Justice in New York City, ${ }^{78}$ the Transitional Justice Centre at the University of Ulster, ${ }^{79}$ and the Centre for Transitional Justice and Post Conflict Reconstruction in Ontario. ${ }^{80}$ The increasing importance of TJ not only as an investigative pool but also as a platform for a border-crossing and interdisciplinary collaboration among human-rights scholars, criminal lawyers, international lawyers, anthropologists and sociologists, reflects on the complexity of issues addressed under the heading of TJ. It is this complexity that the present volume wishes to address in order to bring together the work of some of the leading scholars in the field. But, at the same time, the essays in this book encompass an even wider range of aspects than that already falling within the ambit of TJ. We approximate TJ with the equally complex field of L\&D because, on the one hand, we think that the issues just addressed in association with

76

Naomi Roht-Arriazza, "The New Landscape of Transitional Justice, in: Naomi Roht-Arriaza \& Javier Mariecurrena (eds), Transitional Justice in the Twenty-First Century: Beyond Truth Versus Justice, (Cambridge, Cambridge University Press, 2006), p 1, at 2.

${ }^{80} \mathrm{http}: / /$ tjcentre.uwo.ca. 
transitional justice have, in many ways, been central, explicitly or implicitly, in the work carried out by L\&D scholars and practitioners. On the other, however, we believe that the dialogue between L\&D and TJ about shared concerns and research targets is only in its early stages, ${ }^{81}$ and is likely to produce a significant increase in our understanding of the intricate connections between development and aid policies, laws and economics, on the one hand, and the continuously proliferating field of transitional justice, on the other. ${ }^{82}$

The collected essays in the area of L\&D in this volume build on seminal scholarship since the 1970s, a time at which hopes even on the political left were particularly high with regard to the potential for law to play a significant role in the aid and assistance programmes that were being rolled out under the policy directives of the International organisations and the United States. ${ }^{83}$ As terms such as "development", "aid" and "reform" would suggest, one of the most treacherous aspects of the associated programmes was the implicit assumption of competence, authority and - arguably - righteousness - in the design and delivery of such "assistance" programmes to countries around the world. ${ }^{84}$ Critique against a predominantly Western- and, more precisely, United States-spirited wave of "assistance" and "development" programmes formed early and consistently, pointing to the pitfalls of policy programmes which all too often prioritised the relevance of private commercial enterprise over the pursuit of public policy, ${ }^{85}$ and, in dramatic ways, neglected to account for the causes of the current state of countries now receiving "assistance". ${ }^{86}$ Similarly, a poignant critique raised in the

81 In that regard, see, for example, de Greiff \& Duthie, note 66 above; Yvette Selim \& Tim Murithi, "Transitional Justice and Development: Partners for Sustainable Peace in Africa?", (2011) 6 Journal of Peacebuilding and Development, p 58; see, also, Susanne Buckley-Zistel, "Connecting Transitional Justice and Development", presentation made at the Conference "The Contribution of Civil Society and Victim Participation in Transitional Justice Processes", 2009, available at: http://www.victimparticipation.org/files/Buckley-Zistel.pdf, and the speech by UNDP Administrator, Helen Clark, on 14 November 2011 on "A Role for Development in Transitional Justice: the Arab Spring and Beyond", available at: http://www.undp.org/content/undp/en/home/presscenter/speeches/2011/11/14/helen-clarka-role-for-development-in-transitional-justice-the-arab-spring-and-beyond.html (last accessed 28 October 2012).

82 See, for example, the contributions to the International Journal of Transitional Justice, created in 2007, available at: http://www.oxfordjournals.org/our_journals/ijtj/about.html.

83 See the self-critical assessment by Trubek \& Galanter, note 1 above, p 1062.

84 For a poignant deconstruction of the "progress" vs. "underdeveloped" assertions informing the World Bank's conceptualisation of developmental aid, see Pahuja, Decolonising International Law, note 5 above.

85 For an illustration of this approach, see the influential essay by Richard A Posner, "Creating a Legal Framework for Economic Development”, (1998) 13 The World Bank Research Observer, p 1.

86 John Brohman, "Economism and Critical Silences in Development Studies: A Theoretical Critique of Neoliberalism, (1995) 16 Third World Quarterly, p 297; Stephen N Ndegwa, “A Case against Structural 
context of a number of humanitarian-aid initiatives was the failure of those designing the programme to consider more adequately the deeper, "root" causes of the conflicts at the centre of the interventions.

A pertinent aspect of the increasing overlap of $L \& D$ and $T J$ is the role of law and, particularly, that of rights. Human rights were central to early assessments of states of "underdevelopment" and, as a consequence, the development of a rights regime, embedded in a system of "rule of law", was seen as an essential prerequisite in the facilitation of societal, legal, economic and political progress. ${ }^{88}$ However, as critics have long been arguing, human rights do not exist in a vacuum, but can only be explained within a comprehensive legal system, creating manifold rights and countervailing duties and obligations. ${ }^{89}$ In the context of L\&D, the critique of rights focused, even at an early stage, on the volatility of human rights assertions in precarious political conditions, characterised by social-economic inequality and great disparages in the actually existing access to justice conditions. Even "advanced" stages of L\&D reform, introducing concerns with the "social", fell privy to a convincing critique of the programmes' failure to facilitate and to consolidate a solid rights and entitlements regime, rather than complementing insufficient rule-of-law implements with arbitrary welfare or equity insertions. ${ }^{90}$

This focus on the centrality - but precariousness - of rights in the context of postconflict, transitional states and emerging economies continues to be a central concern in the evolving regulatory and normative landscape of development and transitional justice. To the degree that human rights have come to represent institutionalised entitlements, which are both instruments of power as well as bargaining chips in struggles over autonomy and

Adjustment”, (1997) 2 New Political Economy, p 318 (1997); Kate Manzo, “Africa in the Rise of Rightsbased Development", (2003) 34 Geoforum, p 437.

87 See, for example, Bettina Scholdan, "Addressing the root causes: Relief and development assistance between peacebuilding and preventing refugee flow", (2000) The Journal of Humanitarian Assistance, available at: http://sites.tufts.edu/jha/archives/category/bettina-scholdan.

${ }^{88}$ For a comprehensive discussion and critique, see Alvaro Santos, "The World Bank's Uses of the 'Rule of Law' Promise in Economic Development", in: David M Trubek \& Alvaro Santos (eds), The New Law and Economic Development: A Critical Appraisal, (Cambridge-New York, Cambridge University Press, 2006), p 253.

89 See, for example, Robert L Hale, "Coercion and Distribution in a Supposedly Non-Coercive State", (1923) 38 Political Science Quarterly, p 470, and Morris R Cohen, "Property and Sovereignty", (1927) 13 Cornell Law Quarterly, p 8.

90 Kerry Rittich, "The Future of Law and Development: Second Generation Reforms and the Incorporation of the Social”, (2004) 26 Michigan Journal of International Law, p 199. 
sovereignty, they play a central role in the continuing debates regarding the goals of development and transition.

These debates, to be sure, occur within an immensely complex context, rich with competing assertions of the conditions and trajectories of human-rights developments and of the interests invested in granting rights to these or other concerns. ${ }^{91}$ The scope of such contestations has, however, largely expanded, to the degree that policy concerns as expressed, for example, in the context of development or transitional justice programmes, have become quasi-boundary-less. In other words, questions pertaining to the role of law in post-conflict Iraq or the World Bank's leadership in aid to Africa are, in many ways, no longer confined to these particular destinations. Instead, these concerns have become global in the way that they raise pressing questions which tie issues related to Iraq to those associated with global concerns with security and stability in the Middle East, with human-rights protection, as well as with economic interests and geo-political considerations. Likewise, any attempt even at "helping" or "developing" Africa (or, India, ${ }^{92}$ or Latin America ${ }^{93}$ ) would have to start by taking into account the complex and intricate history of Africa's role in the world, a history that has been told too often from the colonisers' perspective and is now being told from within. ${ }^{94}$ In other words, "rights, development and transitional justice" - the triad, which provides the title elements to our book - have become the central grounds of contestation under the larger umbrella of "global governance", the latter having attained the status of an adequately encompassing - as well as timely depiction of - regulatory and normative challenges which can no longer be confined to the level of the nation state or the sphere of international law. ${ }^{95}$

91 See, for example, Jakob Kirkemann Boesen \& Tomas Martin, “Applying a Rights-Based Approach. An Inspirational Guide for Civil Society”, (Copenhagen, The Danish Institute for Human Rights, 2007), available at: www.humanrights.dk/files/pdf/Publikationer/applying.

92 See, for example, Partha Chatterjee, The Nation and its Fragments: Colonial and Postcolonial Histories, (Princeton NJ, Princeton University Press, 1993), and idem, The Politics of the Governed: Reflections on Popular Politics in Most of the World, (New York, Columbia University Press, 2004).

93

See, for example, Antony Anghie, Imperialism, Sovereignty and the Making of International Law, (Cambridge, Cambridge University Press, 2005); Daniel Bonilla Maldonado (ed), Constitutionalism of the Global South: The Activist Tribunals of India, South Africa and Colombia, (New York, Cambridge University Press, 2013).

94 See, for example, the works by the late Chinua Achebe. In this regard, see, also, Obiora Chinedu Okafor, The African Human Rights System, Activist Forces and International Institutions, (Cambridge, Cambridge University Press, 2007).

95 See, for example, Allen Buchanan \& Robert O Keohane, "The Legitimacy of Global Governance", (2006) 


\section{MAPPING GLOBAL GOVERNANCE DISCOURSES: CONVERGENCE, CONTESTATION AND CRITIQUE}

The present volume can be read as a contribution to the body of scholarly responses to the changes in global governance since the end of the Cold War, especially in the unfolding "post September 11, 2001" period, which have identified a re-configuration, at the levels of both theory and practice, of formerly isolated fields and concerns, including human rights, law, and development, as well as post-conflict or, transitional justice. ${ }^{96}$ The task of surveying each of these fields would be Sisyphean, not only because their boundaries appear, across a survey of various types of literature, as both fluid and porous, but also because the number of publications both within and among them continues to multiply. Furthermore, we have recognised that even the implied standpoint from which one might undertake such a survey cannot be presumptively assumed, neither by ourselves as editors, nor by the individual contributors. There are no innocent starting-points. And yet, this does not imply an abdication of the responsibility to engage critically with these rapidly evolving discourses. Rather, the aim of the volume is precisely to draw attention to an extant body of critical scholarship that assumes this task. Not only do these essays individually offer nuanced accounts from a range of contexts in which human-rights advocacy and transitional-justice initiatives are increasingly in collision with development projects, programmes and objectives, ${ }^{97}$ but collectively, they might be read as the beginning, partial and evocative, to be sure, of a methodological mapping of a re-invigorated and globalised field of critical legal scholarship.

In the first part of the volume, the chapters explore the dimensions and dynamics of human-rights discourse in the development context. ${ }^{98}$ In recent years, the apparent

20 Ethics and International Affairs, p 4 (2006), the contributions to David Held \& Anthony McGrew (eds), Governing Globalization: Power, Authority and Global Governance, (Cambridge-Malden MA, Polity PressBlackwell Publishing, 2002), and to Thomas Hale \& David Held (eds), Handbook of Transnational Governance. Institutions and Innovations, (Cambridge-Malden MA, Polity Press, 2011).

96

See, only, Kerry Rittich, "The Future of Law and Development: Second Generation Reforms and the Incorporation of the Social", (2004) 26 Michigan International Law Journal, p 199; Sundhya Pahuja, "Rights as Regulation: The Integration of Development and Human Rights", in: Bronwen Morgan (ed), The Intersection of Rights and Regulation: New Directions in Sociolegal Scholarship, (Aldershot-Burlington VT, Ashgate Publishing, 2007)

97 On this, see, also, César Rodríguez-Garavito, "Ethnicity.gov: Global Governance, Indigenous Peoples, and the Right to Prior Consultation in Social Minefields", ( 2011) 18 Indiana Journal of Global Legal Studies, p 263.

98 David Trubek, "Toward a Social Theory of Law: An Essay on the Study of Law and Development", (1972) 82 Yale Law Journal, p 1; David Kennedy, "Laws and Development", in: John Hatchard \& Amana PerryKessaris, (eds), Law and Development: Facing Complexity in the 21st Century, (London, Cavendish Publishing, 2003), p 17; Balakrishnan Rajagopal, International Law from Below: Development, Social 
convergence between the fields of human rights and development, ${ }^{99}$ as expressed in various documents issued by the UN and by development institutions such as the World Bank, have attracted both praise and support from scholars and development practitioners. ${ }^{100}$ Yet, human rights and development, until quite recently, as a matter of professional expertise as well as practical application, had, for a long time, moved along separate tracks. ${ }^{101}$ Indeed, in many post-independence contexts, they were understood as emanating from distinct sources, requiring different sets of policies and programmes, and presenting potentially conflicting demands. ${ }^{102}$ In light of this history, contemporary approaches that posit human rights and development as not only potentially congenial, but also axiomatically and self-evidently so, beg further inquiry. ${ }^{103}$ As one of our authors has observed elsewhere:

"despite the incorporation of human rights into the development agenda and efforts to represent the promotion of both human rights and development as fundamentally coterminous enterprises, it is clear that many questions concerning the links between social and economic rights and the trajectory of social transformation and economic development policy remain." 104

Movements and Third World Resistance, (Cambridge, Cambridge University Press, 2003); Ruth Buchanan, "Reconceptualizing Law and Politics in the Transnational: Constitutional and Legal Approaches", (2009) 5 Socio-legal Review, pp 21-39; Pahuja, note 96 above.

99 Sally Engle Merry, "Anthropology, Law, and Transnational Processes", (1992) 21 Annual Review of Anthropology, p 357; idem, "New Legal Realism and the Ethnography of Transnational Law", (2006) 31 Law \& Society Inquiry, p 975; Christoph Antons \& Volkmar Gessner (eds), Globalisation and Resistance: Law Reform in Asia since the Crisis, (Portland OR, Hart Publishing, 2007); Yves Dezalay \& Bryant Garth (eds.), Lawyers and the Rule of Law in an Era of Globalization, (Oxford, Routledge, 2012)

100 Philip Alston \& Mary Robinson, in: Human Rights and Development: Towards Mutual Reinforcement, (Oxford, Oxford University Press, 2005), identify the effort to find "ways in which the strengths, resources, and support of the international human rights and development communities can be mobilized in order to reinforce one another in their efforts to achieve shared goals" as a key objective of that landmark edited collection.

101 Issa Shivji, (1999) “Constructing a New Rights Regime: Prospects, Problems, Prospects”, (1999) 8 Social and Legal Studies, p 259: "On the global terrain of social and political discourse, the developmental and the human rights discourses were locked in battle. They were polarized and became mutually exclusive. This meant that the developmental discourse and the human rights discourse ran parallel."

102 See, for example, Shivji, ibid., at 260, where he observes that: "the liberal theory (of rights) ruled out of court any link between individual rights and economic justice, while developmental theory was prepared to sacrifice individual rights in the pursuit of socio-economic justice."

103 Celestine Nyamu-Musembi \& Andrea Cornwall, "What is the 'rights-based approach' all about? Perspectives from international development agencies”, IDS Working Paper 234, Institute of Development Studies, November 2004.

104 Ruth Buchanan, Helen Kijo-Bisimba \& Kerry Rittich, “The Evictions at Nyamuma, Tanzania: Structural Constraints and Alternative Pathways in the Struggles over Land”, in: Lucie E White \& Jeremy Perelman 
These questions might also include:

"How economic development priorities are identified, which groups are consulted in the process of formulating them, how policies are implemented and risks and entitlements allocated, and how the associated costs and benefits are distributed." ${ }^{105}$

In so far as the proposed volume is offered as a response to these concerns, it seeks to address both the macro-historical and legal-theoretical dimensions of these questions, as well as the dilemmas presented by their instantiation in particular (symbolic and institutional) locations.

The essays on transitional justice that are featured in the second part of the volume similarly engage with the complexity of increasingly intertwined discourses. It is here, in the amorphous and intensely belaboured field of international, local and mixed criminal courts and tribunals, global human-rights discourse and human-rights litigation, ${ }^{106}$ truth commissions, village courts and assertions of "retroactive justice", 107 that the internal dependency of these particularised discourses on the debates addressed in the areas of L\&D, humanitarian intervention and occupation becomes visible. The intensive efforts of humanrights activists, constitutional and criminal-law experts over the past few years to bring human-rights violators to justice, ${ }^{108}$ while scrutinising the challenges arising from "humanitarian interventions" that were not authorised under public international law, ${ }^{109}$

(eds), Stones of Hope: How African Activists Reclaim Human Rights to Challenge Global Poverty, (Stanford 105 CA, Stanford University Press), p 93.

Ibid.

${ }^{106}$ Craig Scott, "Introduction to Torture as Tort: From Sudan to Canada to Somalia", in: idem (ed), Torture as Tort, (Oxford-Portland OR-Antwerp, Hart Publishing-Intersentia, 2001), p 3; Robert Wai, "Countering, Branding, Dealing: Using Economic and Social Rights in and around the International Trade Regime", (2003) 14 European Journal of International Law, p 35-84.

107 Makoto Usami, "Retroactive Justice: Trials for Human Rights Violations under a Prior Regime", in: Burton M Leiser \& Tom D Campbell (eds), Human Rights in Philosophy and Practice, (Aldershot, Ashgate Publishing, 2001), p 423.

${ }^{108}$ See Craig Scott, "Translating Torture into Transnational Tort: Conceptual Divides in the Debate on Corporate Accountability for Human Rights Harms", in: idem, Torture as Tort, note 106 above, p 45, and the other contributions in this volume; see also Beth Stephens, "Translating Filártiga: A Comparative and International Law Analysis of Domestic Remedies for International Human Rights Violations", (2002) 27 Yale Journal of International Law, p 1; see, also, Jeremy Sarkin, "Reparation for Past Wrongs: Using Domestic Courts Around the World, Especially the United States, to Pursue Human Rights Claims", (2004) 32 International Journal of Legal Information, p 426; Arturo J Carrillo, "Bringing International Law Home: The Innovative Role of Human Rights Clinics in the Transnational Legal Process", (2004) 35 Columbia Human Rights Law Review, p 527.

109 See, only, Anne Orford, "Muscular Humanitarianism: Reading the Narratives of the New Interventionism", 
suggest a pressing need for a more encompassing and rigorous critical approach. It has become clear that a better understanding of the present situation of comparative constitutional politics, legal aid and law reform in post-conflict and transition societies crucially depends upon this rethinking.

While several of the chapters (Issa Shivji (Chapter 2), Ananya Mukerjee-Reed (Chapter 3)) acknowledge the segmentation of these fields at the level of practice that, until quite recently, allowed experts in development, for example, to consider rights concerns "somebody else's job", 110 and others (Alywin \& Coombe (Chapter 6)) document new actors and advocacy practices that have emerged in the era of "rights-based development", all of the chapters in the present volume address the role of power inequalities, as well as the important place of social and political contestation in relation to recent developments. These approaches provide an important counterpoint to strands of scholarly and institutional discourse that have been much more sanguine, even celebratory, regarding the potential for new, more encompassing, mechanisms of global governance, in order to avoid the errors and pitfalls of past practices.

The discourse of convergence is illustrated, for example, by UN Secretary General Kofi Annan's 2005 Report, entitled “In Larger Freedom: towards Development, Security and Human Rights for all.” The Report cogently observed:

"we will not enjoy development without security, we will not enjoy security without development, and we will not enjoy either without respect for human rights. Unless all these causes are advanced, none will succeed." ${ }^{112}$

Since the late 1990s, a growing number of international institutions and agencies have taken up this call to move towards a more integrated, or comprehensive, approach. ${ }^{113}$ At the

(2003) 10 European Journal of International Law, p 679; Martti Koskenniemi, “'The Lady doth Protest too much'. Kosovo, and the Turn to Ethics in International Law", (2002) 65 Modern Law Review, pp 159-175; Andreas L Paulus, "The War Against Iraq and the Future of International Law: Hegemony or Pluralism?", (2004) 25 Michigan Journal of International Law, p 691.

${ }^{110}$ Peter Uvin, Human Rights and Development, (West Hartford CT, Kumarian Press, 2004).

111 Hans-Otto Sano, "Development and Human Rights: The Necessary, but Partial Integration of Human Rights and Development”, (2000) 22 Human Rights Quarterly, pp 734-752; de Greiff \& Duthie, note 66 above.

112 In Larger Freedom: Towards Development, Security and Human Rights for All, Report of UN Secretary General Kofi Annan, Chapter 1, http://www.un.org/largerfreedom/chap1.htm, last accessed 11 September 2012.

${ }^{113}$ See, for example, the World Bank, Development and Human Rights: the Role of the World Bank, 
level of practice, one effect of these developments can be traced through the proliferation of projects under the increasingly capacious category of the "Rule of Law".

Our review of the "convergence" literature reveals a tendency to focus on the ways in which the fields can, or should, mutually enforce each other. ${ }^{115}$ It is not uncommon to trace convergences between transitional justice and development upon the basis of their shared aspirations for a better future for the citizens of a particular nation, for example. The contributors to this volume, however, remind us to attend to the ways in which these types of discussion already assume the illusory narrative of progress that lies at the heart of the development project. ${ }^{116}$ Along a different vector, even very robust and otherwise critical analyses of the relationship between development and human rights tend to focus on potential compatibilities, rather than on conflicts. ${ }^{117}$ Yet, the enthusiasm with which the discussion of potential synergies between the fields of development, human rights, and transitional justice has been embraced by both scholars and practitioners has drawn scholarly and public attention away from the difficult choices and necessary trade-offs that are a routine part of the development enterprise. ${ }^{118}$

Rather than joining with the institutional or scholarly quest for an "integrated approach", a number of the essays in this volume identify this move (towards a "comprehensive approach") as a key aspect of contemporary developments which calls for a more differentiated analysis and critique. ${ }^{119}$ One thing that is of particular interest to us is the way in which law, in its technocratic guise, is increasingly understood as instrumental to each

(Washington DC, IBRD, 1998).

${ }^{114}$ Stephen Humphreys, Theatre of the Rule of Law: Transnational Legal Intervention in Theory and Practice, (Cambridge, Cambridge University Press, 2010).

115 Alston \& Robinson, Development and Human Rights, note 100 above.

${ }^{116}$ See Pahuja, note 5 above; Escobar, note 5 above.

${ }^{117}$ Philip Alston, "Ships Passing in the Night: The Current State of the Human Rights and Development Debate Seen through the Lens of the Millennium Development Goals", (2005) 27 Human Rights Quarterly, pp 755829.

${ }^{118}$ Ruth Buchanan, Helen Kijo-Bisimba \& Kerry Rittich, "The Evictions at Nyamuma: Struggles over Land and the Limits of Human Rights Advocacy in Tanzania", in: White \& Perelman, note 104 above.

${ }^{119}$ Sundhya Pahuja, Kerry Rittich, Sally Engle Merry, Chapters 1, 8 and 9 respectively, in this volume. See, also, Luis Eslava \& Sundhya Pahuja, "Beyond the (Post)Colonial: TWAIL and the Everyday Life of International Law", (2012) 45 Journal of Law and Politics in Africa, Asia and Latin America - Verfassung und Recht in Übersee (VRÜ), p 195. 
of these fields: human rights, development and transitional justice. ${ }^{120}$ In a context in which enduring solutions to the world's problems, such as the slogan inscribed on the entrance to the World Bank Building in New York; "Our dream is a world free of poverty", continue to elude the international community, institutions such as the World Bank have embraced the "rule of law" as a development strategy. ${ }^{121}$ The "rule of law" is also understood as fundamental to the success of transitional-justice initiatives, and is seen as essential to greater realisation of international human rights within given states. The turn to law plays an analogous role in each of these fields: in the context of deeply-politicised policy decisions, a technocratic understanding of the "rule of law" both grounds and legitimates the interventions of international agencies in the domestic affairs of states. In this account, it is the understanding of law itself, and particularly the specific role which can be played by a particular conception of the "rule of law" in the international arena that is in transition, rather than human rights, development or transitional justice as such.

Our approach stands in contrast to previous exercises in "bridge-building" between these fields, which have sought to draw these separate strands together from within the functional logics or shared foundational assumptions of one, or occasionally, two fields. ${ }^{122}$ Building upon shared foundations can serve to re-inforce implicit assumptions, rather than subjecting them, as several of our authors do, to closer scrutiny. Within the fields in question, the shared founding assumptions - arguably - include the problematical dichotomies of old world/new world, civilised/barbaric, developed/underdeveloped, donor/recipient, as well as the hierarchies that are both supported and justified by these dichotomies. The unique contribution of the present volume is to pose the encounter between the fields without replicating or assuming the logics that underpin them. That is, this volume both offers critical engagement with these developments and provides us with the opportunity to consider some

${ }^{120}$ On this, see the analysis by Sally Engle Merry, Chapter 8 in this volume; see, also, Galit A Sarfaty, Values in Translation: Human Rights and the Culture of the World Bank, (Stanford CA, Stanford University Press, 2012).

${ }^{121}$ See Pahuja, Decolonising International Law, note 5 above, at 185; see, also, Rittich, note 90 above; see, also, Trubek \& Santos, The New Law and Economic Development, note 1 above.

122 See, for example, de Greiff \& Duthie, note 66 above. See, also, the Book Review of Transitional Justice and Development by Basil Ugochukwu (2012) 13 German Law Journal, p 94. See, also, Alston \& Robinson, note 100 above. Siobhan McInerney-Lankford, "Human Rights and Development: a Comment on Challenges and Opportunities from a Legal Perspective", (2009) 1 Journal of Human Rights Practice, pp 5182; Randall Peerenboom, "Human Rights and Rule of Law: What's the Relationship?", (2004-5) 36 Georgetown Journal of International Law, p 809. 
of the risks presented by the convergence of the teleologies of human rights, development, and transition. Consequently, it is not surprising that many of these chapters are cautious and cautionary, rather than celebratory, regarding recent developments.

In our contemporary engagement with critical scholarship on development, human rights and transitional justice, we have found it useful to re-visit the landmark critique of law and development formulated by David Trubek and Marc Galanter, who identified three categories, or grounds of critique. These are the critique of universality, referring to the ethnocentrism of the liberal legalist paradigm, the critique of formal law's potency and the significance of informal ordering mechanisms, and the "dark face" of legal reform critique, which acknowledges that reform efforts may frequently have consequences such as empowering élites, or containing protest, not intended by liberal reformers. ${ }^{123}$ And, although these insights have been taken up and expanded up by critical scholars in a great many fields over the intervening decades, the persistence of ambitious, formalist and instrumental approaches to law reform in development- and transitional-justice projects, most recently reframed in the language of rights, suggest that legal scholars and lawyers in development contexts continue to be loathe to abandon their disciplinary commitments to legal efficacy, even in the face of considerable evidence to the contrary. For example, a number of scholars have recently both extended and illustrated the argument that, in the encounter with development agencies, human rights have largely become re-formulated as a mode of regulation, in a manner that largely neutralises their potential to be used in contentious politics. ${ }^{124}$ At the same time, critical scholarship also reminds us that the role of political mobilisation on the part of emergent activist groups within this development has never been more significant. ${ }^{125}$ Kerry Rittich sums it up well when she notes that "in second generation reforms, human rights are better understood not as the answer to the social deficit but as the terrain of struggle". ${ }^{126}$ In this contested and uncertain landscape, the work of critical legal

\footnotetext{
123 Trubek \& Galanter, note 1 above pp 1083-84. See, also, Ruth Buchanan, note 1, above.

124 Pahuja, "Rights as Regulation", note 96 above, and "her Global Poverty and the Politics of Good Intentions", in this volume; R Perry, "Preserving Discursive Spaces to Promote Human Rights: Poverty Reduction Strategy, Human Rights and Development Discourse”, (2011) 7 McGill International Journal of Sustainable Development Law and Policy, p 61.

125 White \& Perelman, note 104 above; Rajagopal, note 98 above; R. Buchanan, "Writing Resistance into International Law”, (2008) 10 International Community Law Review, pp 445-454.

${ }^{126}$ K Rittich, "The Future of Law and Development: Second-Generation Reforms and the Incorporation of the Social", in: Trubek \& Santos note 1 above, p 24.
} 
scholars - including those whose essays are included in this collection and the many others cited herein - plays an increasingly vital role in questioning assumptions, containing expectations, and challenging the power of entrenched institutions. The contributions to the present volume mark important milestones in the continuing engagement with law's role in development and transitional justice, and we trust that our readers will find in them a host of helpful and inspiring introductions to a field of discourse which is of growing importance both in inter-disciplinary scholarship as well as in practice. 